\title{
Determining The Factors Preventing Nurses From Breast Self-Examination
}

\author{
Serpil ÇETIN ${ }^{1, a}$ Aliye OKGÜN ALCAN ${ }^{1, b}$ Esra ERIKMEN $^{2, c}$
}

\author{
${ }^{1}$ Nursing Department, Faculty of Health Sciences, Izmir Bakircay University, İzmir, Turkey, TURKEY \\ ${ }^{2}$ Department of Presidency Community Health, Public Health Services, İzmir Provincial Health Directorate, İzmir, TURKEY
}

ORCIDS: ${ }^{\mathrm{a}} 0000-0003-0922-7060$; ${ }^{\mathrm{b}}$ 0000-0002-6889-363X; ${ }^{\mathrm{c}}$ 0000-0002-6282-7746

\begin{abstract}
The promotion of breast self-examination (BSE) in developing countries is the main strategy for reducing breast cancer-related mortality. For this reason, determining the barriers to perform BSE for nurses, who play a key role in the health education of the society, should be a priority step. This research was conducted to determine the barriers to perform BSE for nurses. The sample of this descriptive, cross-sectional study consisted of 276 nurses working in a training and research hospital in Izmir, agreed to participate in the study. The data of the study, which was conducted between January and June 2020, were collected using face-to-face interview method via questionnaire form and Champion Health Belief Model Scale (CHBMS). Number and percentage distribution, One Way ANOVA, Student t-test, Kruskal-Wallis, Mann-Whitney U test, Spearman Correlation and Multiple Regression Analysis were used in data analysis. The mean age of the nurses participating in the study was 32.56 \pm 9.07 . $52.9 \%$ of the nurses are single and the majority $(75.7 \%)$ are university graduates. $73.9 \%$ of the nurses perform BSE. The rate of those who perform BSE at the right time is $40.5 \%$. The difference between the disability, trust and health motivation subdimension mean scores of nurses who perform BSE and those who do not are statistically significant. According to the health belief model which was used to determine the barriers to nurses' BSE performance in this study, disability perception scores were high, the factors that most affect the perception of disability were marriage, having children, the clinic type where they work, breast cancer risk, age, working year and sensitivity, severity as well as benefit, sense of trust and health motivation.
\end{abstract}

Key words: Barriers, Breast self-examination, Health belief model, Nurses.

\section{Hemşirelerin Kendi Kendine Meme Muayenesi Yapmasını Engelleyen Faktörlerin Belirlenmesi}

\begin{abstract}
ÖZET
Gelişmekte olan ülkelerde, kendi kendine meme muayenesinin (KKMM) yaygınlaştırılması meme kanserine bağlı ölüm oranını azaltmanın ana stratejisidir. Bu nedenle toplumun sağlık eğitiminde anahtar rol üstlenen hemşirelerin KKMM yapmasındaki engellerin belirlenmesi öncelikli adım olmalıdır. Bu araştırma hemşirelerin KKMM yapmasındaki engellerin belirlenmesi amacıyla yapıldı. Tanımlayıcı tipte, kesitsel tasarımdaki çalışmanın örneklemini İzmir ilinde bir eğitim araştırma hastanesinde çalışan, araştırmaya katılmayı kabul eden 276 hemşire oluşturdu. Ocak-Haziran 2020 tarihleri arasında gerçekleştirilen çalışmanın verileri yüz yüze görüşme yöntemi ile, anket formu ve Champion Sağlık Inanç Modeli Ölçeği (CSiMÖ) kullanılarak toplandı. Verilerin analizinde sayı ve yüzde dağılımı, One Way ANOVA, Student t-test, Kruskal-Wallis, MannWhitney U testi, Spearman Korelasyon ile Çok Yönlü Regresyon Analizi kullanıldı. Çalışmaya katılan hemşirelerin yaş ortalaması $32.56 \pm 9.07$ idi. Hemşirelerin \%52.9’u bekar, çoğunluğu (\% 75.7) üniversite mezunudur. Hemşirelerin \% 73.9'u KKMM yapmaktadır. KKMM'yi doğru zamanda yapanların oranı \%40.5'dir. KKMM yapan ve yapmayan hemşirelerin güven, engel ve sağlık motivasyonu alt boyut puan ortalamaları arasındaki fark istatistiksel olarak anlamlıdır. Bu çalışmada hemşirelerin KKMM yapmasındaki engelleri tespit etmek için kullanılan sağlık inanç modeline göre engel algısı puanlarının yüksek olduğu, engel algısını en çok etkileyen faktörlerin evlilik, çocuk sahibi olma, çalışıan klinik, meme kanseri riski taşıma, yaş, çalışma yılı ile duyarlıık, ciddiyet, yarar, güven algısı ve sağlık motivasyonu olduğu saptandı.
\end{abstract}

Anahtar kelimeler: Engeller, Hemşire, Kendi kendine meme muayenesi, Sağlık inanç modeli. 


\section{INTRODUCTION}

Breast cancer, which affects approximately 2.1 million women annually, accounts for approximately $15 \%$ of all cancer deaths in women. Breast cancer is the most common type of cancer seen in women worldwide and is the leading cause of all cancer deaths for women living in less developed countries (Bray et al., 2018 World Health Organization (WHO), 2018). According to WHO, approximately $58 \%$ of breast cancer deaths occur in less developed countries. Considering that 570.000 women died due to breast cancer in 2015 worldwide (WHO, 2018), the early diagnosis of breast cancer is part of increasing survival rates and improving health outcomes for survivors (Bray et al., 2018). According to WHO and the American Cancer Society, survival and medical treatment rates of breast cancer patients increase with the diagnosis and screening in the earlier stages of cancer (WHO, 2018). Among screening methods, breast self-examination (BSE) is a cost-effective, convenient, painless, easily applicable, special, safe, and non-invasive method (Beydağ and Yürügen, 2010). Furthermore, it raises health awareness and allows a woman to recognize her breast tissue (Johson, 2019). In studies, it was reported that the mortality risk was lower among women who reported that they performed BSE and that cancer appeared for the first time in its advanced stages (III and IV) in most of the patients with breast cancer (Martei et al., 2018). Zejda and Kaleta (2020) reported that breast cancer was diagnosed by BSE in $63.7 \%$, by clinical examination in $13.5 \%$, and by mammography in $22.8 \%$ of women who recovered from breast cancer. Therefore, these findings once again remind the necessity of early diagnosis.

Most women in developing countries do not perform BSE although it is recommended (Türk et al., 2017). There are many reasons why women do not perform BSE but the most important barrier for women not to perform BSE is the lack of information (Tabari et al., 2017; Heena et al., 2019). Nurses are in continuous communication with patients and are responsible for both their health and individuals' health due to their educational and supportive roles. Therefore, their professional responsibilities are to regularly perform BSE, which is important for the early diagnosis of breast cancer and to teach it to women around them (Heena et al., 2019).
Moreover, they should pay attention to their health and be a role model for their patients. In addition to all these, previous studies showed that nurses who work longer are at an increased risk of breast cancer compared to nurses who work less. Therefore, considering that nurses are among the risk group for breast cancer, it is very important to diagnose breast cancer at an early stage (Santi et al., 2015). For this reason, it is important to identify the barriers, attitudes, and beliefs that prevent nurses from BSE.

Health beliefs play an important role in guiding individuals to exhibit preventive health behaviors. For this reason, the Health Belief Model (HBM) is widely used to form the theoretical framework of the studies on BSE (Gözüm et al., 2004). Because beliefs are effective on health behaviors of individuals and the HBM is one of the most important behavior change models. And BSE is widely used to assess beliefs about preventive health behaviors such as clinical breast examination and mammography (Akhtari-Zavare et al., 2013). It also involves concepts that allow predicting why people take preventive action to detect or control a disease (Al-Battawi and Sofar, 2018). The negative relationship between screening behaviors and barrier perception and the positive relationship between confidence, sensitivity, benefit, seriousness, and health motivation form the basis of HBM. Therefore, perceived barriers is directly effective in exhibiting protective health behaviors (Kılıç et al., 2009). In this study, factors that prevent nurses from performing BSE were evaluated within the scope of barrier perception, a sub-dimension of HBM. Determining the barriers of nurses in performing early diagnosis methods for breast cancer will allow the planning of health services and will create a source for the literature. However, it was seen in studies that nurses do not perform BSE (Ceylan 2017) and very few studies have investigated the reasons for this. Therefore, the aim of this study was to determine the factors that prevent nurses from performing such an important method, BSE.

\section{MATERIALS AND METHOD}

The research was carried out with nurses working in a training and research hospital in the province of Izmir. Izmir is located in western Turkey and is the third largest city in the 
country. The mentioned hospital has 570 beds and employs a total of 380 nurses.

This descriptive, cross-sectional study was conducted retrospectively between January and June 2020. The population consisted of nurses working in the relevant hospital and the sample consisted of female nurses aged 18 and over who voluntarily agreed to participate in the study. Since it was planned to reach the entire population in the study, no sample calculation was made. In the study, $72.6 \%$ of the population was reached ( $n=276$ ).

\section{Data Collection Tools}

The data were collected using a questionnaire form prepared by the researchers in line with the literature and the Champion Health Belief Model Scale (CHBMS) through face-to-face interviews after the participants signed the informed consent form.

The questionnaire form includes nineteen questions about nurses' socio-demographic characteristics, presence of chronic diseases, time of employment, employment type, and breast examination. The CHBMS was used to determine the beliefs of nurses about BSE; the perceivec barriers sub-dimension of CHBMS was used to determine the barriers in performing BSE performance. The scale has six sub-dimensions: susceptibility, seriousness, benefit, barrier, confidence, and health motivation. The scale was first developed by Victoria Champion in 1984 and has 42 items regarding six sub-dimensions of HBM (Champion, 1984). Since the score is calculated for each sub-dimension, the total score is not calculated. Perceived susceptibility indicates one's perception of a certain risk of disease; perceived seriousness determines how a person feels about his/her situation; perceived benefits indicate one's perception of positive health consequences on performing a particular health behavior; perceived barriers express barriers to exhibiting health behavior; health motivation refers to beliefs and behaviors related to health problems; perceived effectiveness expresses confidence in the ability to adopt a health behavior (Karayurt and Dramalı, 2007). The internal consistency Chronbach alpha coefficient of the subdimensions varies between 0.69 and 0.90 ; the test-retest values vary between 0.45 and 0.70 ; invariance against time varies between 0.89 and 0.99. The Turkish version of CHBMS was found to be a valid and reliable tool in determining beliefs and behaviors regarding breast cancer and BSE. Permission was taken from Karayurt who performed the validity and reliability study of the scale. In this study, the Cronbach Alpha reliability coefficients of the scale were found to range between 0.43 and 0.82 (Karayurt and Dramalı, 2007).

\section{Data Analysis}

The SPSS 21.0 package program was used to analyze the data. The study data were analyzed using the descriptive statistical methods (mean, standard deviation, median, frequency, ratio, minimum, maximum) and the distribution of the data was evaluated with the Kolmogorov Smirnov Test. Kruskal-Wallis, Mann Whitney U test, Spearman Correlation Analysis were used for nonparametric data. The student's t-test, One-Way ANOVA test were used for parametric data The significance level was taken as $p<0.05$. Multiple Linear Regression Analysis was performed to identify the effect of the variables that prevent BSE performance. The stepwise regression method was performed to determine which of the independent variables contributed significantly to predicting BSE performance.

\section{RESULTS}

The mean age of the nurses participating in the study was $32.56 \pm 9.07$ (min:18, max:57); $52.9 \%$ of the nurses were single; the majority $(75.7 \%)$ were university graduates. The ratio of those who had children was $41.7 \%$. The mean time of employment of the nurses was $8.86 \pm 9.63$. Of the nurses, $40.2 \%$ were employed in surgical services, $28.3 \%$ in internal medicine service, $12.3 \%$ in intensive care units, $12 \%$ in management departments and outpatient clinics, and 7.2\% in operating rooms. $33 \%$ of the nurses worked only during the day and $3.6 \%$ worked only at night. The ratio of those who worked daytime but also as the nurse on call at night once, 2-3 times and 4-5 times a month were $4.7 \%$, $12.3 \%$, and $31.5 \%$, respectively.

$25 \%$ of the nurses had a chronic disease. Of those with a chronic disease, 26\% had hypertension, 24\% had a circulatory system disease, 18\% had diabetes, 14\% had a neurological disease, and $10 \%$ had a digestive system 
disease. When the breast cancer risk factors were evaluated, it was seen that $85.9 \%$ of the nurses had a risk (Table 1).

Table 1. Breast Cancer Risk Factors of Nurses

\begin{tabular}{|c|c|c|}
\hline Status & $\mathrm{n}$ & $\%$ \\
\hline $\begin{array}{l}\text { Risk factor } \\
\text { Yes } \\
\text { No }\end{array}$ & $\begin{array}{c}237 \\
39 \\
\end{array}$ & $\begin{array}{l}85.9 \\
14.1 \\
\end{array}$ \\
\hline $\begin{array}{l}\text { Breast cancer in the family } \\
\text { Yes } \\
\text { No }\end{array}$ & $\begin{array}{c}27 \\
249\end{array}$ & $\begin{array}{c}9.8 \\
90.2\end{array}$ \\
\hline $\begin{array}{l}\text { Obesity } \\
\text { Yes } \\
\text { No } \\
\end{array}$ & $\begin{array}{l}45 \\
231 \\
\end{array}$ & $\begin{array}{l}16.3 \\
83.7 \\
\end{array}$ \\
\hline $\begin{array}{l}\text { Childbirth } \\
\text { Yes } \\
\text { No }\end{array}$ & $\begin{array}{l}135 \\
141 \\
\end{array}$ & $\begin{array}{c}48.9 \\
51.1\end{array}$ \\
\hline $\begin{array}{l}\text { First delivery at } 30 \text { and above } \\
\text { Yes } \\
\text { No }\end{array}$ & $\begin{array}{c}24 \\
252 \\
\end{array}$ & $\begin{array}{c}8.7 \\
91.3\end{array}$ \\
\hline $\begin{array}{l}\text { Oral contraceptive } \\
\text { Yes } \\
\text { No } \\
\end{array}$ & $\begin{array}{c}51 \\
225 \\
\end{array}$ & $\begin{array}{l}18.5 \\
81.5 \\
\end{array}$ \\
\hline $\begin{array}{l}\text { Alcohol } \\
\text { Yes } \\
\text { No } \\
\end{array}$ & $\begin{array}{c}18 \\
258 \\
\end{array}$ & $\begin{array}{r}6.5 \\
93.5 \\
\end{array}$ \\
\hline $\begin{array}{l}\text { Smoking } \\
\text { Yes } \\
\text { No }\end{array}$ & $\begin{array}{c}62 \\
214 \\
\end{array}$ & $\begin{array}{l}22.5 \\
77.5 \\
\end{array}$ \\
\hline $\begin{array}{l}\text { Fibroadenoma of the breast } \\
\text { Yes } \\
\text { No }\end{array}$ & $\begin{array}{r}60 \\
216 \\
\end{array}$ & $\begin{array}{l}21.7 \\
78.3 \\
\end{array}$ \\
\hline $\begin{array}{l}\text { Early menarche ( } 12 \text { years } \downarrow \text { ) } \\
\text { Yes } \\
\text { No }\end{array}$ & $\begin{array}{c}42 \\
234 \\
\end{array}$ & $\begin{array}{l}15.2 \\
84.8 \\
\end{array}$ \\
\hline $\begin{array}{l}\text { Menopause } \\
\text { Yes } \\
\text { No } \\
\end{array}$ & $\begin{array}{c}5 \\
271 \\
\end{array}$ & $\begin{array}{c}1.8 \\
98.2 \\
\end{array}$ \\
\hline $\begin{array}{l}\text { Receiving radiotherapy } \\
\text { Yes } \\
\text { No }\end{array}$ & $\begin{array}{c}9 \\
267\end{array}$ & $\begin{array}{c}3.3 \\
96.7\end{array}$ \\
\hline
\end{tabular}

$73.9 \%(n=204)$ of the nurses performed BSE. The ratio of those who performed BSE regularly was $40.5 \%$. The ratio of nurses who had clinical examination was $25.4 \%(n=70)$ and the ratio of those who had mammography was $8.3 \%(n=23)$.

When the CHBMS sub-dimension scores of the nurses participating in the study were examined, it was found that the mean score on the perceived susceptibility was $7.38 \pm 2.26$, the total score on health motivation was below average by $26.62 \pm 5.46$, the scores on the perceived seriousness, perceived benefit, perceived barriers, and confidence were above average by $22.21 \pm 5.66,16.27 \pm 3.75,23.19 \pm 6.03$, and $36.93 \pm 7.02$, respectively.

When the mean CHBMS sub-dimension scores of the nurses were compared according to their BSE performance, it was seen that the health motivation and confidence scores of those who performed BSE were higher than those who did not, that the mean barrier perception score of those who did not perform BSE was higher than those who performed BSE, and that the difference between them was statistically significant (Table 2).

Table 2. Comparison of Mean CHBMS Sub-Dimension Scores According to the Status of Performing BSE

\begin{tabular}{|c|c|c|c|c|}
\hline $\begin{array}{l}\text { Sub- } \\
\text { dimensions }\end{array}$ & $\begin{array}{c}\text { BSE } \\
\text { performance }\end{array}$ & Mean \pm sd & $t$ & $p$ \\
\hline $\begin{array}{l}\text { Susceptibility } \\
\text { perception }\end{array}$ & $\begin{array}{l}\text { Yes } \\
\text { No }\end{array}$ & $\begin{array}{l}7.40 \pm 2.32 \\
7.32 \pm 2.14\end{array}$ & $\begin{array}{l}.265 \\
.275\end{array}$ & .784 \\
\hline $\begin{array}{l}\text { Seriousness } \\
\text { perception }\end{array}$ & $\begin{array}{l}\text { Yes } \\
\text { No }\end{array}$ & $\begin{array}{l}22.12 \pm 5.61 \\
22.50 \pm 5.87\end{array}$ & $\begin{array}{l}-.491 \\
-.480\end{array}$ & .632 \\
\hline $\begin{array}{l}\text { Benefit } \\
\text { perception }\end{array}$ & $\begin{array}{l}\text { Yes } \\
\text { No }\end{array}$ & $\begin{array}{l}16.47 \pm 3.74 \\
15.71 \pm 3.75 \\
\end{array}$ & $\begin{array}{l}1.485 \\
1.484 \\
\end{array}$ & .140 \\
\hline $\begin{array}{l}\text { Barrier } \\
\text { perception }\end{array}$ & $\begin{array}{l}\text { Yes } \\
\text { No }\end{array}$ & $\begin{array}{r}22.22 \pm 5.90 \\
25.96 \pm 5.61\end{array}$ & $\begin{array}{l}-4.684 \\
-4.798 \\
\end{array}$ & $.0001^{* *}$ \\
\hline Confidence & $\begin{array}{l}\text { Yes } \\
\text { No }\end{array}$ & $\begin{array}{l}38.10 \pm 6.59 \\
33.65 \pm 7.21\end{array}$ & $\begin{array}{l}4.799 \\
4.597\end{array}$ & $.0001^{* *}$ \\
\hline $\begin{array}{l}\text { Health } \\
\text { Motivation }\end{array}$ & $\begin{array}{l}\text { Yes } \\
\text { No }\end{array}$ & $\begin{array}{l}27.30 \pm 5.43 \\
24.69 \pm 5.12\end{array}$ & $\begin{array}{l}3.556 \\
3.658\end{array}$ & $.0001^{* *}$ \\
\hline
\end{tabular}

Mann Whitney U Test

${ }^{*} p<0.05 \quad{ }^{* *} p<0.01$

In the study, when the characteristics of the nurses were compared to CHBMS scores, it was found that the susceptibility perception score of those who were single was lower than those who were married ( $U: 7462,0 ; p=0.002 ; p<0.01)$, that the 
benefit perception score of those who were single was higher than those who were married ( $U: 8089,0 ; p=0.031 ; p<0.05)$, and that the difference between them was statistically significant. Nurses who had children had higher seriousness perception ( $U: 8089,0 ; p=0.003 ; p<0.01)$ and barrier perception ( $U: 8426,0$ $p=0.017 ; p<0.05)$ scores and lower benefit perception scores ( $U: 8444,0 ; p=0.012 ; p<0.05)$ compared to the group without children and this difference was statistically significant. There was no statistically significant relationship between educational status and CHBMS sub-dimensions. When the clinics where the nurses worked and CHBMS sub-dimensions were compared, it was found that the perceived benefit score of those working in the operating room was lower than those who worked in surgical and internal medicine clinics $(K W=10,095 ; p=0.039 ; p<0.05)$. This difference was statistically significant. The barrier perception score was higher in those working in the operating room compared to the other groups and the difference was found to be statistically significant ( $K W=14,772 ; p=0.005 ; p<0.01)$.

When breast cancer risk and CHBMS sub-dimensions were compared, it was found that the barrier perception score of the nurses with breast cancer risk was lower than those who had no risk $(U=7700,5 ; p=0.001 ; p<0.01)$ and that the difference was statistically significant. Likewise, the group with breast

Table 3. Results of Multiple Linear Regression Analysis Performed to Predict Barrier Perception by Independent Variables

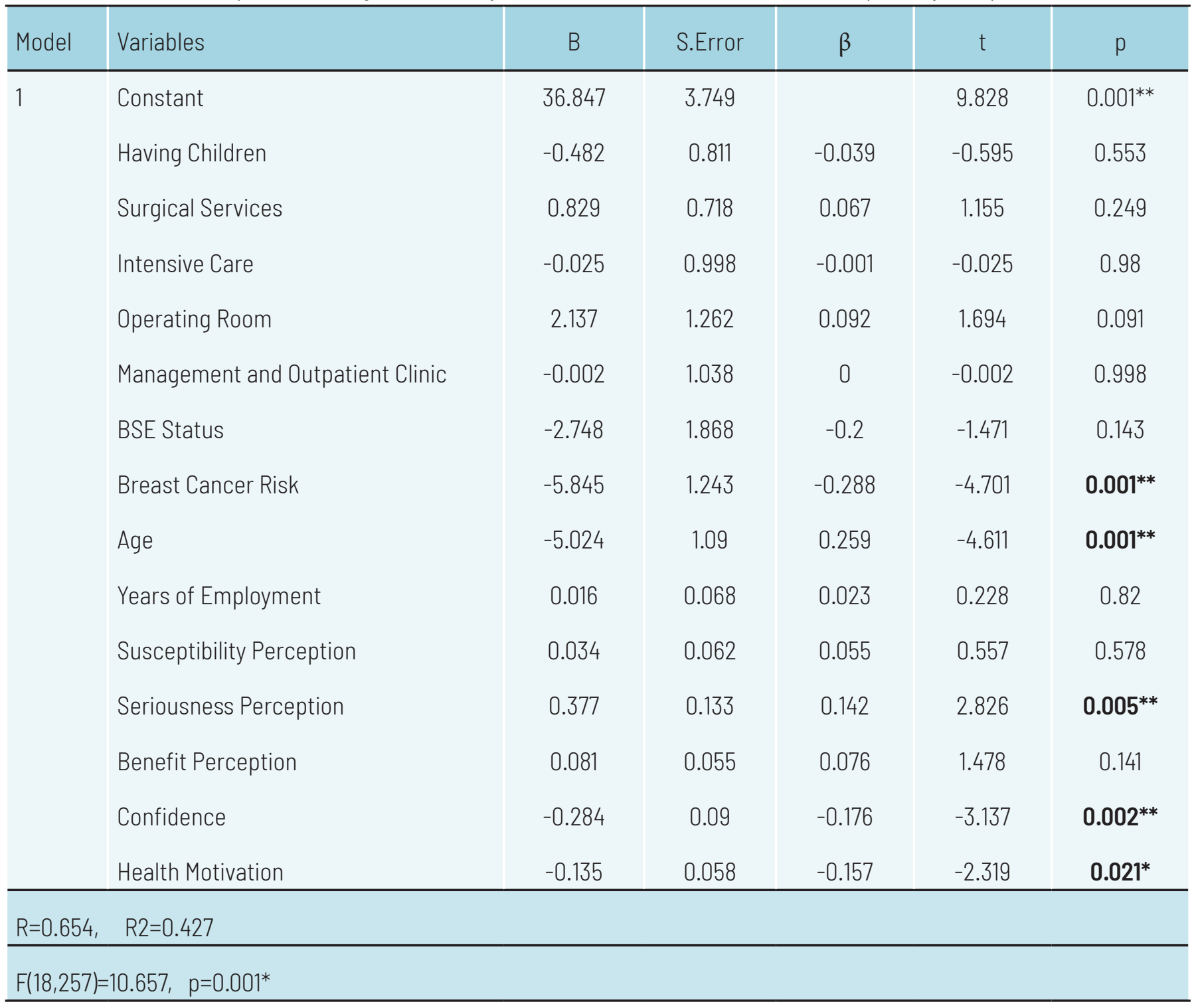


cancer risk had higher confidence ( $U: 7640,5 ; p=0.001 ; p<0.01$ ) and health motivation $(U=7308,5 ; p=0.001 ; p<0.01)$ scores compared to the group without risk and the difference was found to be statistically significant.

According to Table 3, the results of Multiple Linear Regression Analysis performed to determine the effect of independent variables on barrier perception was found to be statistically significant $(F(1,198)=10.657, p<0.001)$. A moderate positive significant relationship was found between the independent variables and barrier perception $(R=0.654, p<0.001)$. Independent variables in the model explained $42.7 \%$ of the total variance in barrier perception ( $R 2=0.427, p<0.001$ ).

When the regression coefficients were examined, it was seen that breast cancer risk $(\beta=-0.288, p<0.01)$, confidence $(\beta=-0.176, \quad p<0.01)$, and health motivation $(\beta=-0.157, \quad p<0.01)$ variables had a negative and seriousness perception ( $\beta=0.142$; $p<0.01)$ and age $(\beta=0.259, p<0.01)$ had a positive significant effect on barrier perception. As a result, nurses with breast cancer risk were found to have a low barrier perception. Furthermore, barrier perception increased as confidence and health motivation decreased, and age increased.

In our study, there was a positive, weak significant relationship between susceptibility perception and seriousness perception $(r=.219, p<0.01)$ and a positive, weak significant relationship between susceptibility perception and barrier perception $(r=.126, p<0.05)$. No statistically significant difference was determined between susceptibility perception and benefit perception, confidence, and health motivation ( $p>0.05)$. A positive, weak significant relationship was found between seriousness perception and barrier perception $(r=.123, p<0.05)$ and a negative, weak significant relationship was found between seriousness perception and health motivation ( $r=-$ .154, $\mathrm{p}<0.05)$. There was no statistically significant relationship between seriousness perception and benefit perception and confidence ( $p>0.05)$.

In our study, there was a positive significant relationship between barrier perception and susceptibility perception $(r=.126, p<0.05)$, a positive significant relationship between barrier perception and seriousness perception ( $r=.120$, $p<0.05)$, a negative significant relationship between barrier perception and benefit perception $(r=-.288)$, a negative significant relationship between barrier perception and confidence $(r=-.431, \quad p<0.01)$, and a negative significant relationship between barrier perception and health motivation $(r=-.237, p<0.01)$.

\section{DISCUSSION}

Nurses have a key role in combating breast cancer. In our study in which we aimed to determine nurses' barriers in performing BSE, it was found that most of the nurses $(73.9 \%)$ performed BSE. This ratio is higher than those in Poland (63.7\%) (Zejda and Kaleta, 2020), Ethiopia (56.3\%)(Mekonnen, 2020) and Korea (40\%) (Lee 2003) and lower than that in Nigeria (77.6\%) (Akhigbe and Omuemu, 2009) regardless of considering performing BSE at the right time and with a correct technique. In the study conducted by Chowdhury et al. (2016) in the USA, the rate of performing BSE was lower (66.2\%) compared to our study; however, the rate of undergoing mammography was found to be higher $(49.9 \%)$. Moreover, almost half of the nurses (40.5\%) in our study stated that they regularly performed BSE at the right time. Likewise, in a study conducted with midwives/nurses in Turkey, $76.1 \%$ of midwives and nurses performed BSE and the ratio of those who regularly performed was 44.2\% (Kulakçı and Korkmaz, 2019). In other studies conducted in Turkey, it was reported that the ratio of performing BSE at the right time varied between 15\% and $81.3 \%$ (Bakır and Demir, 2020; Canbulat and Uzun, 2008). These results reveal that the ratio of regularly performing BSE, which is still recommended for developing countries, is low even among nurses. This is concerning and identifying the barriers regarding this is important.

When the CHBMS sub-dimension scores of the nurses in our study were evaluated, it was found that the mean susceptibility and seriousness perception scores were lower and the mean health motivation, benefit perception, and barrier subdimension scores were higher compared to the study of Bakır and Demir (2020). In the literature (Erbil and Bölükbaş 2012; Karayurt and Dramalı 2007), sub-dimension scores differ in various studies. It was thought that these differences were due to the different time, environments, and cultures of the elements that constitute HBM.

In our study, nurses who had children had higher barrier perception scores compared to married nurses who did not 
have children. This suggested that nurses perceived having children as a barrier to performing BSE.

Alvur, Çınar, and Zengin (2019) found that nurses with high education levels had lower mean barrier perception scores than those with low education levels. This finding suggested that high education level has a positive effect on health beliefs and behaviors. Safajou, Soltani, and Amouzeshi (2017) investigated the barriers of nurses and midwives in breast cancer screening and found that there was a significant relationship between age, marital status, education, and duty term and BSE and that having children increased BSE performance. However, in our study, it was found that the significant difference with the CHBMS sub-dimension scores was not due to the education level but the clinic where the nurses worked. For instance, the barrier perception score was higher, and the benefit perception score was lower in the nurses working in the operating room compared to the other groups. This suggested that the clinic type was an effective factor in performing BSE. Likewise, Demir and Bakır (2020) found that barrier perception scores of nurses working in surgical clinics were higher and benefit perception scores were lower; however, there was no statistically significant difference between them. The number of studies examining this information in the literature is limited. This finding was considered a variable that should be emphasized in future studies.

Similar to our study, Özoğul and Sucu (2019) conducted a study with women working at university and found that women with breast cancer risk had lower barrier perception and higher confidence perception and health motivation. According to HBM, confidence perception refers to the perceived individual effectiveness in the ability to perform BSE (Gürsoy et al., 2011). It can be said that women with breast cancer risk, whether they are healthcare professionals or not, perceive fewer barriers to perform BSE, have higher health motivations, and more individual effectiveness.

In our study as we considered the most important barrier to the realization of behavior is barrier perception according to the Health Belief Model (Champion and Skinner, 2008) we used the barrier sub-dimension of CHBMS to determine the barriers of nurses in performing BSE. The barrier sub-dimension consists of 11 items: lack of knowledge about BSE, fear of BSE results, embarrassment to perform BSE, lack of time for BSE, forgetting to perform BSE, lack of a suitable place for BSE, not performing it because health personnel performed it, not performing it because of undergoing mammography, finding breasts large/lumpy and having more important life events than performing BSE. In our study, the mean score obtained from the barrier sub-dimension was $23.2 \pm 6.04$. Canbulat and Uzun (2008) conducted a similar study with physicians, nurses, and midwives and found the barrier perception scores as $13.13 \pm 5.60,17.42 \pm 7.94$, and $15.89 \pm 7.22$, respectively. This finding shows that barrier perception was significantly lower than that in our study. Again, in the same study, the ratio of performing BSE was $81.3 \%$ among healthcare professionals. This result was considered an indicator that barrier perception is one of the most important factors in exhibiting a behavior. In the study of Karayurt and Dramalı (2007) the barrier perception score of nurses performing BSE was found to be $18.84 \pm 4.40$ and the barrier perception score of nurses who did not perform BSE was found to be 22.96 \pm 7.02 . The barrier perception score of the nurses participating in our study was much higher compared to the literature and this important factor should be investigated in detail.

In their review, Tarawneh and Al-atiyyat (2012) examined 12 studies that determined the barriers in women to perform BSE and revealed that there are many factors that prevent most women in different countries from performing breast cancer examination and that these are cultural, socio-demographic, socio-economic, behavioral, and educational factors. Again, in the literature, one of the factors affecting breast selfexamination is reported to be women's insufficient knowledge about BSE and its application. The low level of knowledge of BSE decreases the rates of BSE performance (Al- Battawi and Sofar 2018; Jumah 2013). However, this finding is valid only for women other than healthcare professionals. There are few studies examining the barriers of nurses in performing BSE. When the effect of variables obtained from these studies on barrier perception was evaluated, it was found that the factors that prevent from performing BSE were having children, the clinic of employment, having the risk of breast cancer, age, time of employment, and susceptibility, seriousness, benefit, confidence perceptions, and health motivation. In their study, 
Tabari et al. (2017) examined 15 articles and evaluated the barriers to performing breast self-examination among women. Barriers to performing BSE were reported to be variables regarding knowledge, cultural factors (shame), psychological factors (fear and anxiety). Aksoy et al. (2015) reported that women's barriers to performing early breast cancer diagnosis tests arise from their lack of knowledge. In the same study, it was emphasized that the lack of knowledge about the signs and symptoms of breast cancer and treatment of the disease at an early stage should be eliminated and that midwives/ nurses have a key role in raising the awareness of women about early screening tests. As a result, eliminating the barriers to performing BSE among nurses who are responsible for the health education of society can be emphasized and indepth research on the subject is recommended.

According to the Health Belief Model, the ratio of exhibiting preventive health behaviors decreases as long as barrier perception is superior to benefit perception (Kılıç et al., 2009). In our study, a positive relationship was found between barrier perception and susceptibility and seriousness perceptions, and a negative relationship was found between benefit, confidence perceptions and health motivation. This finding suggested that susceptible nurses and nurses with high perceived seriousness also perceive barriers with high perception and that nurses with higher perceived benefit and confidence, and health motivation scores had very low level barrier perception. Again, the superiority of barrier perception on benefit perception was considered as explaining the low ratio of performing BSE among nurses.

In their study, Altıntaş and Aslan (2019) found that barrier perception scores of nurses decreased as nurses' years of employment increased, but this was not statistically significant. Contrary to this study, when the correlation between the nursing years and CHBMS sub-dimension scores was examined in our study, it was found that barrier perception increased as the nursing years increased $(r=.214$, $p<0.01$ ). Again, some studies (Santi et al., 2015) showed that the risk of breast cancer increased as the years of employment increased and that nurses with an employment period of 10 years or above had an increased risk of breast cancer. Given that, this situation is concerning. For this reason, the relevant data should be emphasized in training programs.

Eliminating barriers for women to performing BSE and increasing perceived self-efficacy is important to increase health motivation, generalize low-cost clinical breast examination, and promote BSE. Nurses can make a significant change in the general perspective of female patients regarding screening practices and can affect their attitudes and beliefs positively. However, the basis of all these is the elimination of barriers of nurses to performing BSE. In our study, it was concluded that barrier perception scores were high according to the Health Belief Model we used to determine the barriers of nurses to performing BSE and that the factors that affect barrier perception the most were marriage, having children, the clinic of employment, having the risk of breast cancer, age, years of employment, susceptibility, seriousness, benefit, confidence perceptions, and health motivation.

\section{CONCLUSION}

Breast cancer early diagnosis practices should be given more attention in nurses' undergraduate education and post-graduate training programs because of the high risk of breast cancer and their role as a model in the education of society. It should be ensured that individuals learn better by using active training methods, especially those including HBM as the results obtained from this study showed that the susceptibility of nurses to BSE should be increased.

\section{Limitations}

The limitation of our study is that it was carried in a single center. Therefore, the results cannot be generalized to all nurses. However, this study provides important information about the current knowledge and practices of nurses on BSE methods and barriers to performing it. The results encourage further studies on the subject to evaluate the barriers to performing BSE.

\section{Ethical Consideration}

Prior to the study, ethical approval was obtained from the Clinical Research Ethics Committee of the relevant hospital (Dated: 29.01.2020 Decision Number:05). The nurses participating in the study were informed about the purpose of the study and told that the obtained information would only be used for this study, and their verbal and written consent 
was taken.

\section{AUTHOR CONTRIBUTIONS}

Idea/concept: SS, AOA; Design: SÇ, AOA; Consulting: SC, AOA; Data collection: $S S, E E_{i}$ Analysis and/or interpretation: $S C_{\text {, }}$ $A 0 A$, EE; Source review: SÇ, AOA; Writing the article: SÇ, AOA, $\mathrm{EE}_{i}$ Critical review: $S \zeta_{1}, \mathrm{AOA}$

\section{CONFLICT OF INTEREST}

The authors declare no conflict of interest.

\section{FINANCIAL DISCLOSURE}

No financial and/or moral support that could adversely affect the decisions about the study was received from any commercial company that had a direct connection with the subject of the study.

\section{REFERENCES}

Akhigbe A0, Omuemu V0. (2009). Knowledge, attitudes and practice of breast cancer screening among female health workers in a Nigerian urban city. BMC Cancer. 9:203. doi: 10.1186/1471-2407-9-203.

Akhtari-Zavare M, Juni M, Said S, Ismail I. (2013). Beliefs and behavior of Malaysia undergraduate female students in a public university toward breast self-examination practice. Asian Pac J Cancer Prev. 14(1):57-61.

Aksoy Erkal Y, Çeber Turfan E, Sert E, Mermer G. (2015). Meme Kanseri Erken Tanı Yöntemlerine Ilişkin Engeller. J Breast Health. 11:26-30. doi: 10.5152/tjbh.2014.2296

Al-Battawi J, Sofar S. (2018). Utilization of health belief model as a guide for prediction of breast self-examination. International Journal for Research in Health Sciences and Nursing. 4(1):46-63.

Altıntaş HK, Aslan GK. (2019). Meme Kanseri Kaderciliği Algısının Ebelerin ve Hemşirelerin Meme Kanseri Sağlığı Innançlarına Etkisi. Hacettepe Üniversitesi Hemşirelik Fakültesi Dergisi, 6 (1), 10-19. DOl: 10.31125 / hunhemsire.544103

Alvur TM, Çınar N, Zengin H. (2019). Health belief model and breast canser in Sakarya: a cross sectional study. Uluslararası Hakemli Akademik Spor Sağlık ve Tıp Bilimleri Dergisi, (30), 52-67.

Bakır N, Demir C. (2020). Hemşirelerin Meme Kanseri, Kendi Kendine Meme Muayenesi ve Mamografiye IIlişkin Inançlarının Belirlenmesi. CBU-SBED. 7(3): 266 -271

Beydağ KD, Yürügen B. (2010).The effect of breast selfexamination (BSE) education given to midwifery students on their knowledge and attitudes. Asian Pac J Cancer Prev. 11(6)::1761-4.
Bray F, Ferlay J, Soerjomataram I, Siegel RL, Torre LA, Jemal A. (2018). Global cancer statistics. GLOBOCAN estimates of incidence and mortality worldwide for 36 cancers in 185 countries. CA: a cancer journal for clinicians. 68(6):394424.

Canbulat N, Uzun 0. (2008). Health beliefs and breast cancer screening behaviors among female health workers in Turkey. Eur J Oncol Nurs. 12(2),148-56.

Ceylan S. (2017). Kadın Sağlık Çalışanlarının Kendi Kendine Meme Muayenesi Uygulamalarına Sağlık Inanç Düzeylerinin Etkisi, Üsküdar Üniversitesi, Sağlık Bilimleri Enstitüsü, Yüksek Lisans Tezi. İstanbul.

Champion VL. (1984). Instrument development for health belief model constructs. Adv Nurs Sci. 6:73-85. 26.

Champion VL, Skinner CS. (2008). The health belief model. health behavior and health education: theory, research, and practice. Glanz K, Rimer BK \& Viswanath K. San Francisco. Jossey-Bass.

Chowdhury R, David N, Bogale A, Nandy S, Habtemariam T, Tameru B. (2016). Assessing the Key Attributes of Low Utilization of Mammography Screening and Breastself Exam among African-American Women. J Cancer. 7(5):532-7. doi: 10.7150/jca.12963.

Erbil N, Bölükbaş N. (2012). Beliefs, attitudes, and behavior of Turkish women about breast cancer and breast self-examination accordingto a Turkish version of the Champion health belief model scale. Asian Pacific J Cancer Prevention. 13(11), 5823-5828.

Gözüm S, Karayurt 0̈, Aydın i.. (2004). Meme Kanseri Taramalarında Champıon'un Sağlık İnanç Modeli Ölçeğinin Türkçe Uyarlamlarına İlişkin Sonuçlar. Hemşirelikte Araştırma Geliştirme Dergisi. 6(1):71-85.

Gürsoy AA, Mumcu HK, Çalık KY, Bulut HK, Nural N, Kahriman, et.al. (2011). Attitudes and health beliefs associated with breast cancer screening behaviors among Turkish women. Journal of Transcultural Nursing. 22(4),368-375.

Heena H, Durrani S, Riaz M, AlFayyad I, Tabasim R, Parvez G, Abu-Shaheen A. (2019). Knowledge, attitudes, and practices related to breast cancer screening among female health care professionals: a cross sectional study. BMC Womens Health. 19(1):122. doi: 10.1186/s12905-019-0819-x.

Karayurt Ö, Dramalı A. (2007). Adaptation of champion's health belief model scale for Turkish women and evaluation of the selected variables associated with breast selfexamination, Cancer Nurs. 30(1):69- 77.

Kılıç D, Sağlam R, Kara Ö. (2009). Üniversite öğrencilerinde meme kanseri farkındalığını etkileyen faktörlerin incelenmesi. Meme Sağlığı Dergisi. 5(4), 195-199. 
Lee EH. (2003. Breast Self-Examination Performance Among Korean Nurses. Journal for Nurses in Staff Development. 19:81-87.

Martei YM, Pace LE, Brock JE, Shulman LN. (2018). Breast cancer in low- and middle-income countries: Why we need pathology capability to solve this challenge. Clin Lab Med. 38:161

Mekonnen BD. (2020). Breast selfexamination practice and associated factors among female healthcare workers in Ethiopia: A systematic review and meta-analysis. PLoS ONE. 15(11): e0241961. https://doi.org/10.1371/journal. pone.0241961

Özoğul E, Sucu G. (2019). Üniversitede Çalışan Kadınların Meme Kanserinde Erken Tanıya Yönelik Sağlık Inançları. Dokuz Eylül Üniversitesi Hemşirelik Fakültesi Elektronik Dergisi. (12)4:264-273.

Safajou F, Soltani N, Amouzeshi Z. (2017). Barriers to Breast Cancer Screening in Nursing and Midwifery Personnel of Hospitals of Birjand, Iran. Mod Care J. 14(1):e11720. doi: 10.5812/modernc. 11720 .

Santi SA, Meigs ML, Zhao Y, Bewick MA, Lafrenie RM, Conlon MS. (2015). A case-control study of breast cancer risk in nurses from Northeastern Ontario, Canada. Cancer Causes Control. 26(10):1421-8. doi: 10.1007/s10552-015-0633-1.

Tabari, F, Abbaszadeh R, Torabi S, Amini F. (2017). Barriers of breast self-examination: A review study from Iranian researchers. Bali Medical Journal. 6(3), 562-568.

Tarawneh E, Al-atiyyat N. (2012). Exploration of Barriers to Breast-self Examination and awareness. a review. Middle East Journal of Nursing. 6(4).

Türk R, Eroğlu K, Terzioğlu F, Taşkın L. (2017). An Example from the Rural Areas of Turkey: Women Breast Cancer Risk Levels and Application and Knowledge Regarding Early Diagnosis-Scan of Breast Cancer. J Breast Health. 13(2):67-73. doi: 10.5152/tjbh.2017.2557.

World Health Organisation [WHO]. (2018, March14). Cancer fact sheets: Breast cancer. Retrieved from http://www. who.int/cancer/prevention/diagnosis-screening/breastcancer/en/ (Erişim Tarihi: 10.01.2021)

Zejda JE, Kaleta A. (2020). Modes of Early Detection of Breast Cancer in Katowice Region, Poland. Int J Environ Res Public Health. Apr 12;17(8):2642. doi: 10.3390/ijerph17082642. 